\title{
ANALISIS EFEKTIFITAS PENDAPATAN PARIWISATA SERTA KONTRIBUSINYA TERHADAP PENDAPATAN ASLI DAERAH (PAD) KOTA SABANG 2014-2018
}

\author{
Muhammad Firrizqi Furqan ${ }^{1}$, Said Muniruddin ${ }^{* 2}$ \\ ${ }^{1,2}$ Program Studi Akuntansi Fakultas Ekonomi Universitas Syiah Kuala \\ e-mail: 1firrizqifurqan@gmail.com ${ }^{1}$, saidmunir@unsyiah.ac.id ${ }^{* 2}$

\section{* Corresponding Author}

\begin{abstract}
Pendapatan Asli Daerah (PAD) adalah penerimaan dari pungutan pajak daerah, pungutan jasa layanan, iuran dari penerimaan lain dinas, laba dari perusahaan daerah dan penerimaan pembangunan yang digali atau dihasilkan oleh daerah yang bersangkutan. Penelitian ini bertujuan untuk mengetahui tingkat efektivitas penerimaan sektor pariwisata di Kota Sabang Tahun 2014-2018 serta mengetahui tingkat kontribusi penerimaan sektor pariwisata terhadap Pendapatan Asli Daerah (PAD) di Kota Sabang Tahun 2014-2018. Penelitian ini bersifat deskriptif dengan pendekatan kuantitatif. Data yang digunakan dalam penelitian adalah data sekunder. Dalam penelitian ini, penulis menggunakan 2 rasio, yaitu rasio efektivitas dan rasio kontribusi. Penelitian ini menghasilkan rasio efektivitas pendapatan pariwisata Kota Sabang periode 2014-2018 rata-rata 135,8\%, dan rasio kontribusi sektor pariwisata Kota Sabang terhadap Pendapatan Asli Daerah (PAD) tahun 2014-2018 senilai 3,71\%.
\end{abstract}

Keywords: Efektivitas, Kontribusi, Pendapatan Asli Daerah, Pendapatan Sektor Pariwisata

\section{Pendahuluan}

Saat Pada awalnya otonomi daerah di Indonesia diwujudkan setelah diberlakukannya Undang-Undang Nomor 22 Tahun 1999 tentang Pemerintahan Daerah, yaitu memberikan peran yang lebih besar kepada kabupaten atau kota dalam penyelenggaraan rumah tangganya. Pemerintah daerah dalam pengelolaan, pembangunan, dan kemasyarakatan harus memenuhi aspirasi masyarakat setempat yang bersangkutan. Sehubungan dengan itu, kebijakan pemerintah daerah tidak diragukan lagi harus diarahkan pada peningkatan kualitas pelayanan yang diserahkan kepada masyarakat melalui pengelolaan keuangan daerah yang bertujuan kepada meningkatkan perannya dalam pembangunan daerah.

Pemerintah daerah memanfaatkan otonomi daerah kepada menggali dan mengembangkan segala potensi daerah yang dimilikinya, termasuk dalam rangka meningkatkan pendapatan daerah. Sebagaimana tertuang dalam Undang-Undang Nomor 23 Tahun 2014 tentang Pemerintahan Daerah, undangundang tersebut menyatakan bahwasanya pemerintah daerah memiliki kewenangan yang luas dalam penyelenggaraan segala urusan publik, mulai dari perencanaan, pelaksanaan, pengawasan, pemantauan, dan evaluasi. Ketentuan mengenai otonomi daerah diharapkan dapat membuat pemerintah daerah lebih mandiri dalam mengelola keuangan daerah. Konsekuensi dari penerapan otonomi daerah ialah setiap daerah harus meningkatkan pendapatan asli daerah (PAD) guna mendanai pekerjaan rumah tangganya sendiri, seperti meningkatkan PAD. Kepada mengoptimalkan pendapatan asli daerah, beberapa item pendapatan daerah perlu ditingkatkan, antara lain pendapatan pariwisata, pajak daerah, hasil pengelolaan kekayaan yang dipisahkan daerah, dan PAD lainnya yang sah.

Pajak dan retribusi bagi pemerintah daerah ialah sumber utama pendapatan (budgetary function) dan fungsi regulasi (regulatory function). Pajak dan retribusi digunakan sebagai sumber pendapatan daerah kepada membiayai belanja pemerintah. Pemerintah daerah perlu mengetahui sumber perolehan PAD yang dapat memberikan kontribusi yang signifikan kepada memajukan daerahnya, salah satunya ialah pendapatan dari sektor pariwisata.. Dilihat dari fenomena tersebut 
terlihat bahwasanyapentingnya pajak dan retribusi bagi daerah terutama kepada mendukung pembangunan daerah itu sendiri menjadi sumber pendapatan yang sangat potensial, karena besaran pajak dan pendapatan yang dibayarkan akan meningkat seiring dengan laju pertumbuhan penduduk, stabilitas ekonomi dan politik.

Pariwisata ialah sumber pendapatan penting bagi daerah. Adanya pariwisata berarti wilayah tersebut akan mendapat pemasukan dari pendapatan setiap objek wisata. Kepada menjadi daerah tujuan wisata, suatu daerah harus lebih menarik kepada menarik wisatawan (Pitana \& Gayatri, 2005: 99). Pariwisata juga menjadi komoditas bagi semua orang, karena berwisata menghilangkan kejenuhan, mengenal warisan sejarah dan budaya, bisa berbelanja dan berbisnis (Austrian, 2005). Kebutuhan akan pariwisata seperti itu semakin hari semakin meningkat, oleh karena itu pariwisata ialah salah satu sektor yang potensial kepada dikembangkan dan menjadi sumber pendapatan daerah. Dalam rangka meningkatkan pendapatan daerah, program pengembangan sumberdaya dan potensi pariwisata dapat memberikan kontribusi bagi pembangunan ekonomi daerah.

Dalam hal ini, pemerintah daerah harus memiliki pengetahuan dan kemampuan kepada mengidentifikasi potensi sumber pendapatan asli daerah, termasuk pajak daerah dan retribusi yang terkait dengan sektor pariwisata. Jika tidak ada perhatian dari pengelola pajak daerah, kontribusi ke sektor tersebut akan menjadi tidak efektif, efisien dan hemat biaya. Hal tersebut pada akhirnya akan merugikan masyarakat dan pemerintah daerah sebagai pemungut sehingga mengakibatkan penerapan pajak dan retribusi daerah kurang optimal (Handoko, 2013).

Berdasarkan situs minanews.net, Pariwisata islami ialah potensi utama dongkrak PAD Kota Sabang. Demikian Asisten Pemerintahan, Keistimewaan dan Kesra Setda Kota Sabang, Andri Nourman AP M.Si, mewakili Walikota Sabang, pada Seminar Muzakarah Wisata Islami yang diinisiasi oleh Majelis Permusyawaratan Ulama (MPU) Kota Sabang yang berlangsung di Aula Mata Ie Resort Sabang, Senin (29/07). "Pariwisata ialah salah satu faktor penting dalam peningkatan PAD, dan tentunya wisata yang kita jalankan ialah wisata yang Islami sesuai dengan Syariat Islam yang berlaku saat ini," ujarnya.

Kota Sabang ialah salah satu kota yang berada di ujung barat Indonesia, yang terletak di Provinsi
Aceh. Kota sabang menurut peraturan pemerintah Republik Indonesia nomor 50 tahun 2011 termasuk kedalam kawasan strategis pariwisata nasional (KSPN), memiliki banyak sumber daya alam khususnya potensi pariwisata yang cukup besar, mulai dari wisata alam, wisata kebudayaan dan wisata sejarah. Ironisnya dengan begitu besarnya potensi yang dimiliki Kota Sabang, pembangunan pada Kota Sabang masih kurang. Sehingga sudah seharusnya pemerintah daerah mengoptimalkan perolehan pajak daerah dan retribusi daerah khususnya sektor pariwisata sebagai sumber dari pendapatan asli daerah. Kemampuan pemerintah dalam menggali sumber perolehan dari sektor pariwisata tersebut harus diikuti dengan kemampuan penetapan target yang sesuai dengan potensi sebenarnya, serta kemampuan pemerintah menekan biaya yang dikeluarkan dalam pemungutannya. Kemampuan tersebut akan menambah perolehan dan menciptakan tingkat efisiensi dan efektivitas yang lebih baik

\section{Kajian Pustaka dan Kerangka Pemikiran Pendapatan Asli Daerah (PAD)}

Pendapatan Asli Daerah (PAD), menurut Widjaja (2001: 42) ialah salah satu aset utama pemerintah daerah dalam menghimpun dana kepada pembangunan dan pemenuhan belanja daerah. PAD juga ialah upaya daerah kepada mengurangi ketergantungan pada pendanaan pemerintah tingkat atas.

Pendapatan Asli Daerah (PAD) ialah bagian dari sumber pendapatan daerah. Dalam mewujudkan otonomi daerah sebagai sumber PAD haruslah dominan dan mampu menanggung biaya yang dibutuhkan daerah. PAD terdiri dari :

1) Hasil Pajak Daerah

2) Hasil Retribusi Daerah

3) Hasil Usaha Perusahaan Daerah

4) Lain-lain Usaha Daerah yang sah

\section{Pajak Daerah}

Menurut Undang-Undang Nomor 34 Tahun 2000, pajak daerah ialah iuran wajib yang dilakukan oleh orang pribadi dan badan kepala daerah tanpa imbalan langsung yang setara, yang dapat diterapkan sesuai dengan peraturan perundang-undangan yang berlaku yang digunakan kepada membiayai 
penyelenggaraan pemerintahan daerah dan pembangunan daerah.

\section{Retribusi Daerah}

Pasal 1 angka 10 Undang-Undang Nomor 28 Tahun 2009 tentang Pajak Daerah dan Retribusi Daerah menjelaskan bahwasanya tanpretribusi ialah pungutan daerah sebagai pembayaran atas jasa atau pemberian izin tertentu yang secara khusus diserahkan oleh pemerintah daerah kepada kepentingan perseorangan atau badan. Retribusi Daerah ialah retribusi yang dipungut sehubungan dengan pelayanan yang diserahkan secara langsung dan nyata, seperti retribusi pelayanan kesehatan, retribusi pelayanan sampah / kebersihan, retribusi pelayanan pemakaman, retribusi jasa usaha pengelolaan limbah cair (Wenny, 2012).

\section{Pariwisata}

Undang-Undang Pariwisata Nomor 10 Tahun 2009 menyebutkan bahwasanyapariwisata ialah salah satu jenis kegiatan pariwisata yang didukung oleh berbagai sarana dan layanan yang diserahkan oleh masyarakat, dunia usaha, pemerintah dan otoritas daerah. Industri pariwisata ialah industri yang sangat penting karena menghasilkan devisa, menghasilkan transaksi triliunan rupiah, menciptakan lapangan kerja dan mendorong pertumbuhan produk. (Dimyati, 2004).

Qanun Kota Sabang Nomor 4 Tahun 2012 tentang pajak daerah Kota Sabang menyatakan bahwa pajak hotel, pajak restoran, pajak hiburan, retribusi tempat rekreasi dan olahraga merupakan pendapatan sektor pariwisata yang lebih diutamakan oleh pemerintah Kota Sabang. Sesuai dengan pernyataan Yoeti (2001), pendapatan pariwisata adalah bagian dari pendapatan asli daerah yang berasal dari kegiatan kepariwisataan, seperti retribusi tempat rekreasi dan olahraga, pajak hotel dan restoran, pajak hiburan, dan lainnya dengan satuan rupiah pertahun.

\section{Efektivitas}

Menurut Halim (2007:166), efektivitas harus dinilai atas tujuan yang bisa dilaksanakan bukan atas konsep maksimum. Jadi, efektivitas ialah ukuran keberhasilan atau kegagalan dari organisasi dalam mencapai suatu tujuan. Apabila dikaitkan dengan efektivitas sektor pariwisata, maka dapat dilihat dengan membandingkan realisasi perolehan dengan target yang telah ditetapkan.

\section{Kontribusi}

Kontribusi menurut Halim (2007) ialah sebagai alat sebagai alat pengukur yang digunakan kepada mengetahui sejauh mana pajak daerah dan retribusi daerah memberikan sumbangan dalam perolehan PAD.

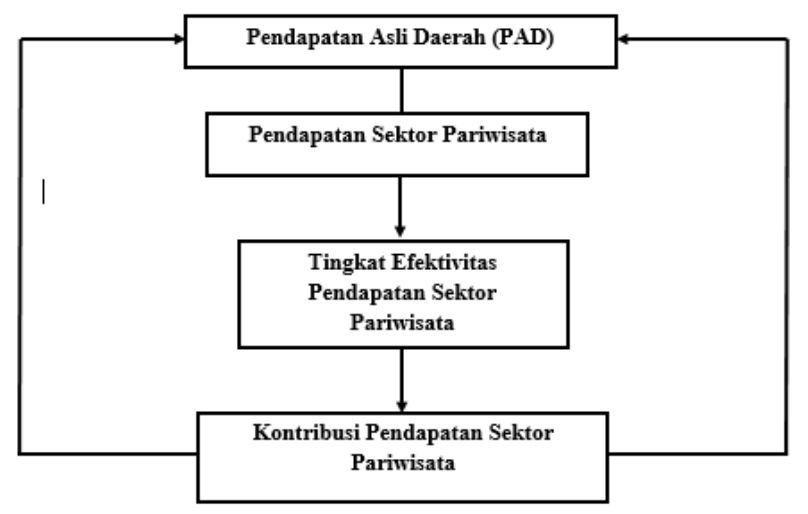

Gambar 2.1. Kerangka Pemikiran

\section{Metode Penelitian}

\subsection{Desain Penelitian}

Desain penelitian merupakan keseluruhan perencanaan dan kerangka kerja untuk menjawab tujuan penelitian yang akan memudahkan peneliti dalam melakukan penelitiannya. Desain penelitian pada dasarnya merupakan cara ilmiah untuk mendapatkan data dengan tujuan dan kegunaan tertentu (Sugiyono, 2014:10).

Sekaran (2017) menjelaskan bahwa terdapat lima aspek dasar yang ada pada desain penelitian. Berikut uraian kelima aspek dasar penelitian:

\section{1) Sifat Studi}

Penelitian ini bersifat deskriptif kuantitatif karena peneliti akan mendeskripsikan pendapatan sektor pariwisata kota Sabang.

2) Situasi Studi

Penelitian ini menggunakan studi yang tidak diatur. Penelitian ini menganalisis data Laporan Realisasi Anggaran (LRA) Pemerintah Kota Banda Aceh Tahun 2014-2018 yang di peroleh dari Laporan Hasil Pemeriksaan (LHP) Badan Pemeriksa Keuangan (BPK) Republik Indonesia.

3) Unit Analisis 
Unit analisis penelitian adalah analisis organisasi, data yang diperlukan dalam penelitian ini yaitu Laporan Realisasi Anggaran (LRA) Pemerintah Kota Sabang Tahun 2014-2018.

4) Horizon Waktu

Horizon waktu yang digunakan dalam penelitian ini adalah longitudinal.

\section{Objek Penelitian}

Objek dalam penelitian ini adalah Laporan Realisasi Anggaran (LRA) Pemerintah Kota Sabang Tahun 2014-2018.

\section{Proses Rencana Penelitian}

Sumber data pada penelitian ini adalah data sekunder. Data sekunder berupa data dokumentasi. Teknik pengumpulan data yang digunakan dalam penelitian ini dengan cara, yaitu penelitian studi dokumentasi.

\section{Data yang Diperlukan}

1. Profil Pemerintah Kota Sabang.

2. Data anggaran dan realisasi pendapatan sektor pariwisata Pemerintah Kota Sabang Tahun 20142018.

3. Data anggaran dan realisasi Pendapatan Asli Daerah (PAD) Pemerintah Kota Sabang Tahun 2014-2018.

\section{Operasional Variabel}

1. Efektivitas Pendapatan Sektor Pariwisata

Efektivitas $=\frac{\text { realisasi penerimaan pendapatan pariwisata }}{\text { target penerimaan pendapatan pariwisata }} \times 100 \%$

Apabila nilai yang dihasilkan lebih besar dari 100 maka dapat dikatakan pendapatan pariwisata semakin efektif, namun apabila nilai yang dihasilkan kurang atau lebih kecil dari 100 maka dapat katakan pendapatan periwisata semakin tidak efektif.

Tabel 3.1

Klasifikasi Kriteria Nilai Efektivitas Pendapatan

Pariwisata

\begin{tabular}{|l|l|}
\hline \multicolumn{1}{|c|}{ Presentase } & \multicolumn{1}{c|}{ Kriteria } \\
\hline$>100 \%$ & Sangat Efektif \\
\hline $90 \%-100 \%$ & Efektif \\
\hline $80 \%-90 \%$ & Cukup Efektif \\
\hline $60 \%-80 \%$ & Kurang Efektif \\
\hline$<60 \%$ & Tidak Efektif \\
\hline
\end{tabular}

Sumber: Mepmendagri No. 690.900.327 Tahun 2006
2. Kontribusi pendapatan sektor pariwisata terhadap PAD

Kontribusi pendapatan pariwisata $=\frac{\text { realisasi pendapatan sektor pariwisata }}{\text { pendapatan asli daerah }} \times 100 \%$

Apabila nilai yang dihasilkan lebih besar dari 50 maka dapat dikatakan kontribusi dari pendapatan pariwisata sangat baik, namun apabila nilai yang dihasilkan kurang atau lebih kecil dari 100 maka dapat katakan kontribusi dari pendapatan periwisata semakin tidak baik.

Tabel 3.1

Klasifikasi Kriteria Nilai Efektivitas Pendapatan Pariwisata

\begin{tabular}{|l|l|}
\hline \multicolumn{1}{|c|}{ Presentase } & \multicolumn{1}{c|}{ Kriteria } \\
\hline $0,00 \%-10 \%$ & Sangat Kurang \\
\hline $10 \%-20 \%$ & Kurang \\
\hline $20 \%-30 \%$ & Sedang \\
\hline $30 \%-40 \%$ & Cukup Baik \\
\hline $40 \%-50 \%$ & Baik \\
\hline$>50 \%$ & Sangat Baik \\
\hline
\end{tabular}

Sumber: Mepmendagri No. 690.900.327 Tahun 2006

\section{Metode Analisis}

Penelitian deskriptif kuantitatif dalam penelitian ini akan menyajikan hasil tentang target dan realisasi penerimaan sektor pariwisata, serta kontribusi penerimaan sektor pariwisata di Kota Sabang tahun 2014-2018. Dalam penelitian ini, penulis akan menggunakan 2 rasio, yaitu rasio efektivitas dan rasio kontribusi. Untuk melakukan perhitungan dan juga agar dapat mengklasifikasikan pendapatan sektor pariwisata tesebut, data dalam penelitian ini diperoleh dari Badan Pemeriksa Keuangan (BPK) Republik Indonesia. Adapun tahapan analisis data yang digunakan dalam penelitian ini ebagai berikut:

1. Membuat tabel target, realisasi, serta tabel penerimaan PAD tahun 2014- 2018 yang datanya diperoleh dari BPK Republik Indonesia.

2. Menghitung tingkat efektivitas per tahun dengan cara membandingkan antara realisasi dengan target penerimaan sektor pariwisata Kota Sabang tahun 2014-2018. Untuk menilai efektifitas, maka dapat disesuaikan dengan tabel klasifikasi tingkat efektivitas.

3. Menghitung tingkat kontribusi sektor pariwisata terhadap PAD. Untuk mengetahui seberapa besar kontribusi terhadap pendapatan asli daerah dengan cara membandingkan realisasi penerimaan sektor 
pariwisata dengan realisasi penerimaan PAD dari tahun ke tahun selama tahun 2014-2018.

4. Membandingkan hasil perhitungan efektivitas dengan klasifikasi tingkat efektivitas, sehingga dapat diketahui apakah termasuk dalam kategori tidak efektif, kurang efektif cukup, efektif, atau sangat efektif.

5. Membandingkan hasil perhitungan kontribusi dengan klasifikasi tingkat kontribusi, sehingga dapat diketahui apakah termasuk dalam kategori sangat kurang, kurang, sedang, cukup baik, baik, atau sangat baik.

\section{Hasil danPembahasan}

\section{Unit Analisis dan Lokasi Penelitian}

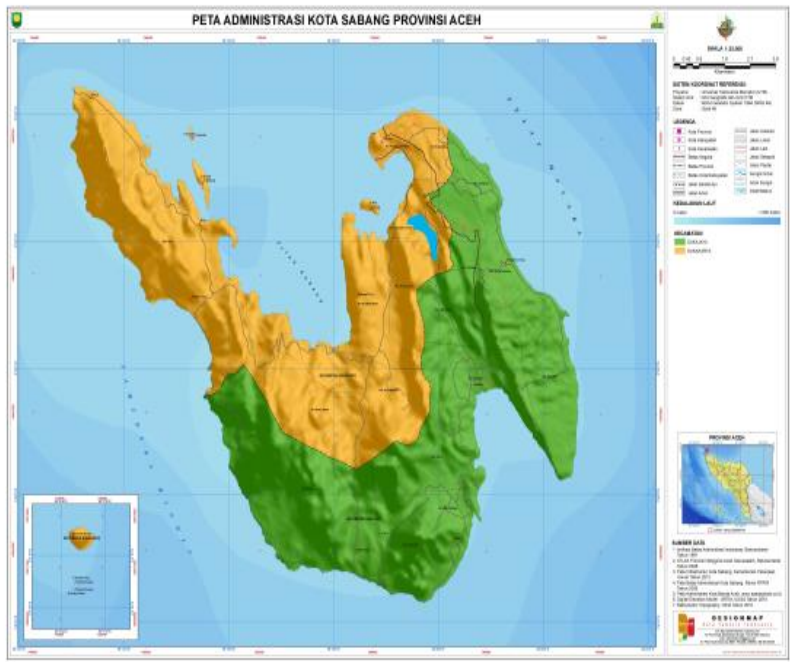

Gambar 4.1

Kota Sabang merupakan wilayah paling barat di Republik Indonesia. Secara Geografis, Kota Sabang terletak pada koordinat 05 o 46' 28 " - 05 o 54' 28 " Lintang Utara (LU) dan 95o 13'02" - 95o22' 36' Bujur Timur (BT) dengan batasan wilayah sebagai berikut :

1. Sebelah utara dan timur berbatasan dengan Selat Malaka,

2. Sebelah selatan berbatasan dengan Selat Benggala

3. Sebelah barat dibatasi oleh Samudera Indonesia.

\section{Analisis Data}

Deskripsi data memberikan gambaran atau deskripsi mengenai karakteristik data variabel yang digunakan dalam penelitian. Gambar 4.2 menunjukkan nilai Frekuensi dari masing-masing variabel.

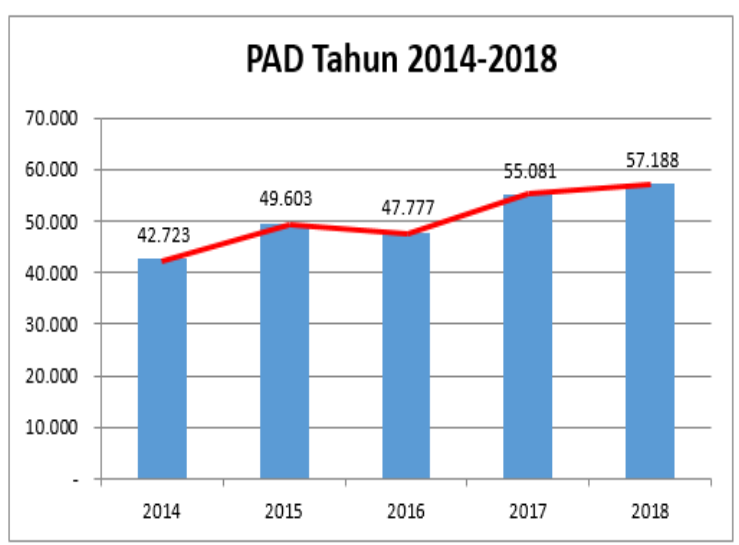

Gambar 4.2 PAD Tahun 2014-2018

Berdasarkan Gambar 4.2 terlihat bahwa PAD yang diterima oleh pemerintah Kota Sabang terus meningkat dari tahun 2014-2018. Penerimaan PAD pada tahun 2018 sebesar 57,1 Milyar dimana terjadi peningkatan sebesar 33,86\% dari tahun 2014

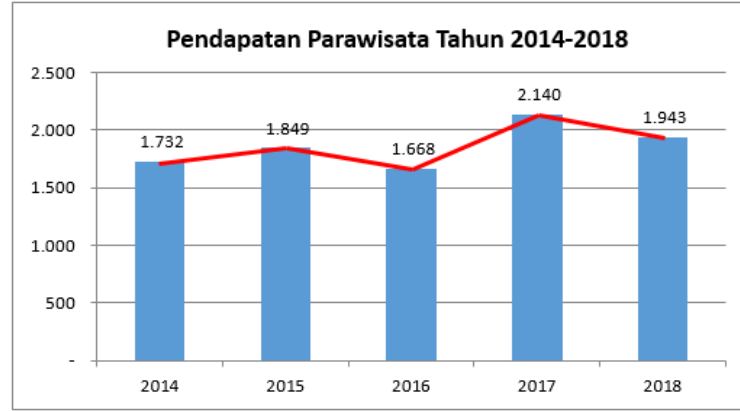

Gambar 4.3 Pendapatan Pariwisata Tahun 2014-2018

Berdasarkan Gambar 4.3 terlihat bahwa pendapatan sektor Pariwisata yang diterima oleh pemerintah Kota Sabang fluktuatif dari tahun 20142018. Penerimaan pendapatan pariwisata pada tahun 2017 dalah yang terbesar yaitu 2,1 Milyar. Pendapatan pariwisata pada tahun 2018 sebesar 1,9 Milyar dimana terjadi peningkatan sebesar 12,18\% dari tahun 2014.

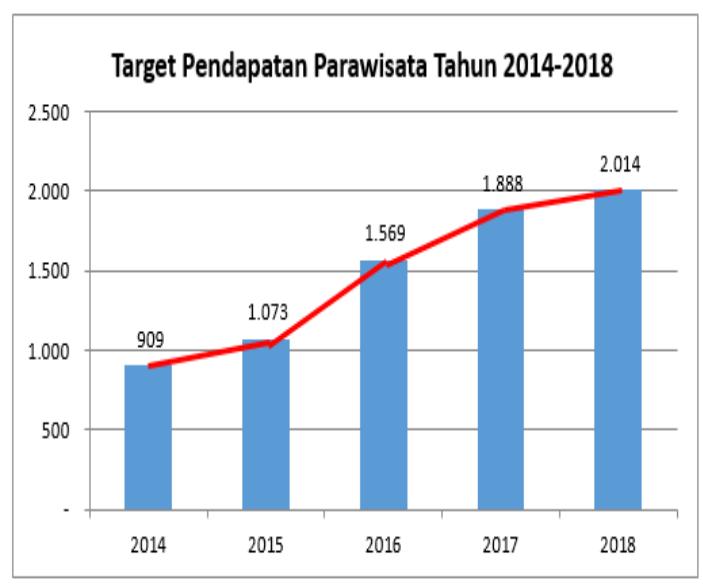

Gambar 4.4 Target Pendapatan Pariwisata Tahun 2014-2018 
Berdasarkan Gambar 4.4 terlihat bahwa target pendapatan sektor Pariwisata yang diterima oleh pemerintah Kota Sabang terus meningkat dari tahun 2014-2018. Target pendapatan pariwisata pada tahun 2018 sebesar 2,1 Milyar dimana terjadi peningkatan sebesar $121,65 \%$ dari tahun 2014.

\section{Analisis Efektivitas}

Tabel 4.1

Perhitungan Tingkat Efektivitas Pendapatan Sektor Pariwisata Kota Sabang Tahun 2014-2018

\begin{tabular}{|c|c|c|c|c|}
\hline Tahun & Target & Realisasi & $\%$ & Kriteria \\
\hline 2014 & 908.686 .100 & 1.731.625.981 & $190,56 \%$ & Sangat Efektif \\
\hline 2015 & 1.073 .174 .000 & 1.849 .492 .485 & $172,34 \%$ & Sangat Efektif \\
\hline 2016 & 1.568 .894 .000 & 1.667 .753 .171 & $106,30 \%$ & Sangat Efektif \\
\hline 2017 & 1.887 .794 .250 & 2.140 .109 .855 & $113,37 \%$ & Sangat Efektif \\
\hline 2018 & 2.014 .086 .208 & 1.942 .548 .720 & $96,45 \%$ & Efektif \\
\hline \multicolumn{3}{|c|}{ Rata-rata } & $135,80 \%$ & Sangat Efektif \\
\hline
\end{tabular}

Berdasarkan Tabel 4.1 di atas rata-rata tingkat efektivitas penerimaan sektor pariwisata dari tahun 2014-2018 adalah sebesar 135,80 berdasarkan kriteria dalam presentase tersebut maka dikategorikan sangat efektif. Dari tabel 4.2 diketahui bahwa tingkat efektivitas terendah terdapat pada tahun 2018 sebesar 96,45\% dengan kategori efektif. Selanjutnya tahun 2016 sebesar 106,30\% sangat efektif, tahun 2017 sebesar $113,37 \%$ dengan kategori sangat efektif, dan tahun 2014 sebesar 190,56\% dengan kategori sangat efektif.

\section{Analisis Kontribusi}

Tabel 4.2

Perhitungan Tingkat Kontribusi Pendapatan Sektor Pariwisata Kota Sabang Tahun 2014-2018

\begin{tabular}{|c|c|c|c|c|}
\hline Tahun & PAD & $\begin{array}{c}\text { Pendapatan } \\
\text { Pariwisata }\end{array}$ & $\%$ & Kriteria \\
\hline 2014 & 42.723 .293 .975 & 1.731 .625 .981 & $4,05 \%$ & Sangat Kurang \\
\hline 2015 & 49.602 .766 .629 & 1.849 .492 .485 & $3,73 \%$ & Sangat Kurang \\
\hline 2016 & 47.776 .631 .105 & 1.667 .753 .171 & $3,49 \%$ & Sangat Kurang \\
\hline 2017 & 55.081 .057 .066 & 2.140 .109 .855 & $3,89 \%$ & Sangat Kurang \\
\hline 2018 & 57.188 .076 .200 & 1.942 .548 .720 & $3,40 \%$ & Sangat Kurang \\
\hline \multicolumn{3}{|c|}{ Rata-rata } & $3.71 \%$ & Sangat Kurang \\
\hline
\end{tabular}

Berdasarkan Tabel 4.2 rata-rata tingkat efektivitas penerimaan sektor pariwisata dari tahun
2014-2018 adalah sebesar 3,71\% dengan kategori sangat kurang. Dari tabel 4.3 terlihat bahwa kontribusi terbesar pada tahun 2014 yaitu sebesar 4,05\% dengan kategori sangat kurang, selanjutnya tahun 2017 sebesar 3,89\% dengan kategori sangat kurang, tahun 2015 sebesar 3,73\% dengan kategori sangat kurang, dan tahun 2018 sebesar 3,40\% dengan kategori sangat kurang.

\section{Pembahasan}

Berdasarkan Tabel 4.2 diketahui bahwa rasio efektivitas terendah terdapat pada tahun 2018 sebesar $96,45 \%$ dengan kategori efektif. Selanjutnya tahun 2016 sebesar 106,30\% sangat efektif, tahun 2017 sebesar $113,37 \%$ dengan kategori sangat efektif, dan tahun 2014 sebesar 190,56\% dengan kategori sangat efektif, dengan rata-rata tingkat efetivitas tahun 20142018 sebesar 135,80\% dengan kategori sangat efektif.

Dari tabel 4.4 terlihat bahwa kontribusi terbesar pada tahun 2014 yaitu sebesar 4,05\% dengan kategori sangat kurang, selanjutnya tahun 2017 sebesar 3,89\% dengan kategori sangat kurang, tahun 2015 sebesar $3,73 \%$ dengan kategori sangat kurang, dan tahun 2018 sebesar 3,40\% dengan kategori sangat kurang, dengan rata-rata kontribusi pendapatan pariwisata tahun 20142018 sebesar 3,71\% dengam kategori sangat kurang.

3.1 Hasil penelitian ini berbeda dengan penelitian yang dilakukan oleh Setyahadi (2009) dimana rata-rata kontribusi pendapatan pariwisata Pada Pemerintah Kabupaten Klaten adalah sebesar $1,98 \%$, sedangkan pada pemerintah kota sabang ratarata kontribusi pendapatan pariwisata sebesar 3,71\%. Pada kategori kriteria penilaian tingkat kontribusi antara pemerintah kabupaten klaten dengan pemerintah kota sabang sama-sama mendapatkan kriteria sangat kurang.

\section{Kesimpulan}

Berdasarkan hasil penelitian diperoleh kesimpulan sebagai berikut.

1. Efektivitas Penerimaan Sektor Pariwisata di Kota Sabang mengalami tingkat persentase yang fluktuatif.Tahun 2014 sampai 2016 mengalami penurunan yang signifikan. Namun, pada tahun 2017 mengalami kenaikan sebesar 7\%. Pada tahun 2018 mengalami penurunan kembali sebesar $16,31 \%$. Persentase 113,37 pada tahun 
2017 dikategorikan sebagai sangat efektif.Tetapi tahun 2018 turun menjadi efektif pada angka $96,45 \%$. Secara keseluruhan, tingkat persentase efektivitas penerimaan sektor pariwisata Kota Sabang tahun 2014-2018 adalah sangat efektif, pada angka $135,8 \%$

2. Kontribusi yang diberikan sektor pariwisata Kota Sabang terhadap pendapatan asli daerah (PAD) sebesar 3,71\% dengan kriteria sangat kurang. Ini menunjukkan bahwa Pemerintah Kota Sabang belum maksimal atau memiliki kinerja yang sangat rendah dalam mengoptimalkan pendapatan pariwisata.

\section{Saran}

1. Kepada pemerintah melalui pihak terkait diharapkan lebih mempertimbangkan lagi target penerimaan pariwisata yang ditetapkan untuk setiap tahunnya realisasi dan keberhasilan yang diperoleh bisa jauh lebih baik.

2. Untuk mempertahankan peningkatan penerimaan sektor pariwisata di Kota Sabang, pemerintah melalui pihak terkait diharapkan dapat terus memberikan pelayanan terbaik, baik bagi wajib pajak sektor pariwisata ataupun wisatawan.

3. Bagi peneliti selanjutnya diharapkan dapat melakukan penelitian yang lebihluas tidak hanya pada Kota Sabang saja, dengan menambah variabel penelitian seperti efisiensi sehingga analisis penelitian menjadi lebih luas. Peneliti juga mengharapkan agar adanya penelitian untuk kabupaten/kota lainnya di Aceh sehingga dapat dilakukan perbandingan antara satu daerah dengan daerah lainnya.

\section{Daftar Pustaka}

Austriana. (2005). Analisis Faktor yang Mempengaruhi Penerimaan Daerah dari Sektor Pariwisata di Jawa Tengah. Desertasi : Fakultas Ekonomi Universitas Diponegoro.

Dimyati. (2004). Mendorong Perekonomian Dengan Pariwisata. Jurnal Dinamika Pembangunan, 1(1), $17-22$.

Halim, A. (2007). Akuntansi Sektor Publik: Akuntansi Keuangan Daerah. Jakarta: Salemba Empat.
Handoko, S. (2013). Analisis Tingkat Efektivitas Pajak Daerah sebagai Sumber Pendapatan Asli Daerah Kota Pontianak. Jurnal Ekonomi Daerah (JEDA) Universitas Tanjungpura Pontianak, 1(1).

Pitana, \& Gayatri, I. G. (2005). Sosiologi Pariwisata. Yogyakarta: Andi.

Sekaran, U. (2009). Research Methods for Business: Metodologi Penelitian untuk Bisnis (4th ed.). Jakarta: Salemba Empat.

Sugiyono. (2014). Metode Penelitian Kuantitatif, Kualitatif, dan Kombinasi (Mixed Methods). Bandung: Alfabeta.

(1999) Undang-Undang Republik Indonesia Nomor 22 Tahun 1999 Tentang Pemerintah Daerah

(2000). Undang-Undang Republik Indonesia Nomor 34 Tahun 2000 Tentang Otomomi Daerah

(2009). Undang-Undang Republik Indonesia Nomor 10 Tahun 2009 Tentang Tentang Kepariwisataan

(2009). Undang-Undang Republik Indonesia Nomor 28 Tahun 2009 Tentang Tentang Pajak Daerah Dan Retribusi Daerah

(2011). Peraturan Pemerintah Republik Indonesia Nomor 50 Tahun 2011 Tentang Tentang Kawasan Strategis Pariwisata Nasional

(2014). Undang-Undang Republik Indonesia Nomor 23 Tahun 2014 Tentang Pemerintahan Daerah 